\title{
Of Spatial and Temporal Entanglements - Narrating a (Chinese) Street in Suburban Johannesburg Photo Essay
}

Romain Dittgen, Mark Lewis and Gerald Chungu

\section{OpenEdition}

\section{Journals}

\section{Electronic version}

URL: http://journals.openedition.org/chinaperspectives/9701

DOI: 10.4000/chinaperspectives.9701

ISSN: 1996-4617

\section{Publisher}

Centre d'étude français sur la Chine contemporaine

\section{Printed version}

Date of publication: 1 December 2019

Number of pages: $37-43$

ISSN: 2070-3449

\section{Electronic reference}

Romain Dittgen, Mark Lewis and Gerald Chungu, "Of Spatial and Temporal Entanglements - Narrating a (Chinese) Street in Suburban Johannesburg", China Perspectives [Online], 2019-4 | 2019, Online since 01 December 2020, connection on 01 April 2021. URL: http://journals.openedition.org/ chinaperspectives/9701 ; DOI: https://doi.org/10.4000/chinaperspectives.9701 


\title{
Of Spatial and Temporal
}

\section{Entanglements - Narrating a (Chinese) Street in Suburban Johannesburg}

\author{
ROMAIN DITTGEN (TEXT), MARK LEWIS (PHOTOGRAPHY), \\ AND GERALD CHUNGU (MAPPING)
}

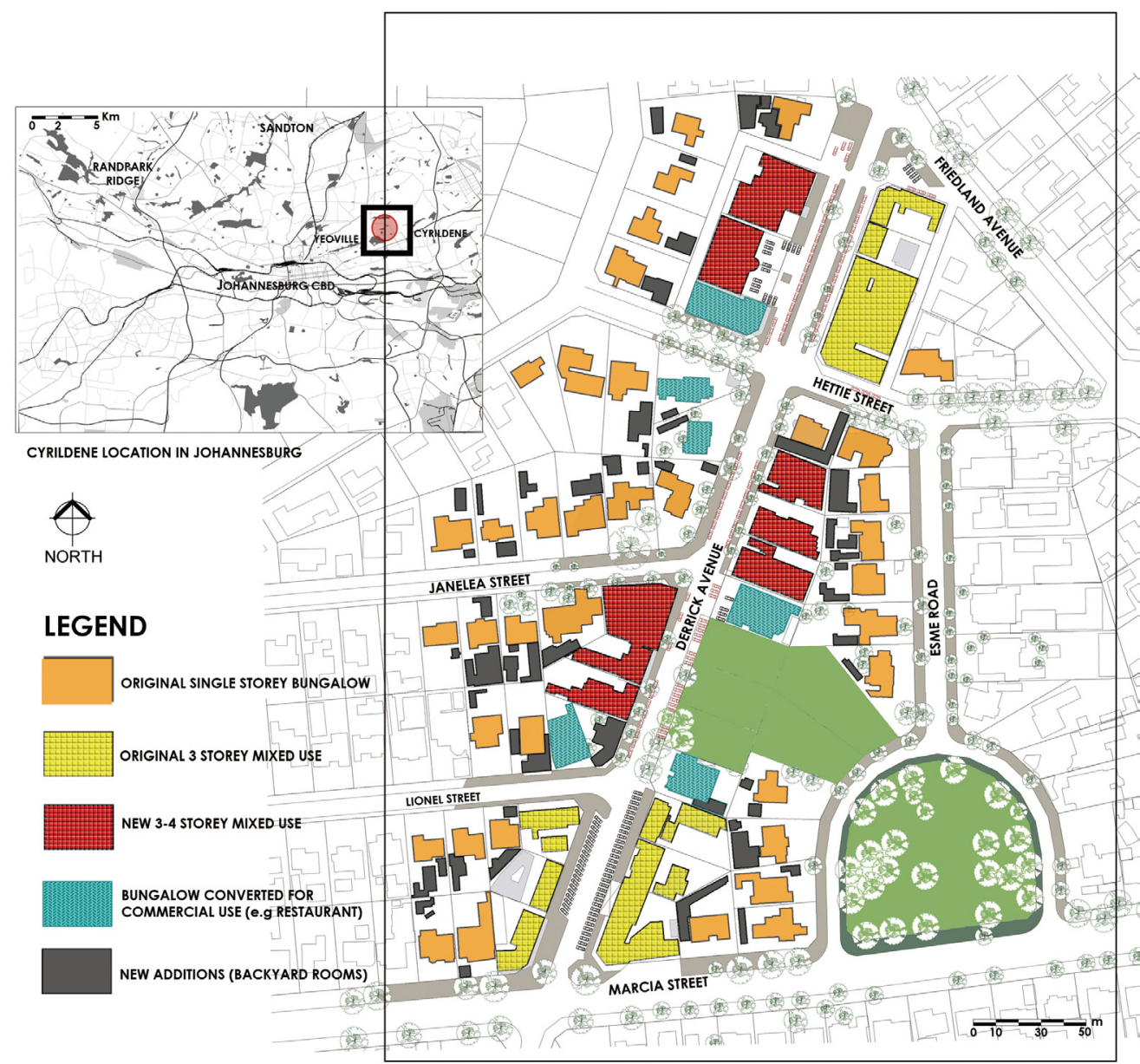

Map. Emerging Building Typologies along Derrick Avenue in Cyrildene. Credit: Cerald Chungu

alfway along Derrick Avenue, a lively high street within the eastern suburb of Cyrildene in Johannesburg, one suddenly comes across a large plot of vacant land. It stands out through the absence of any activity and the discontinuity it creates within the otherwise continuous built environment. Some remnants of outer walls, a house number, and a letterbox point to the previous existence of dwellings, more specifically four freestanding houses located on spacious stands, which have all been demolished. The site being left abandoned for a few years, weeds and bushes have been growing freely, and the stand has partly been used as a dumping ground. After a while, the narrow section between the boundary 


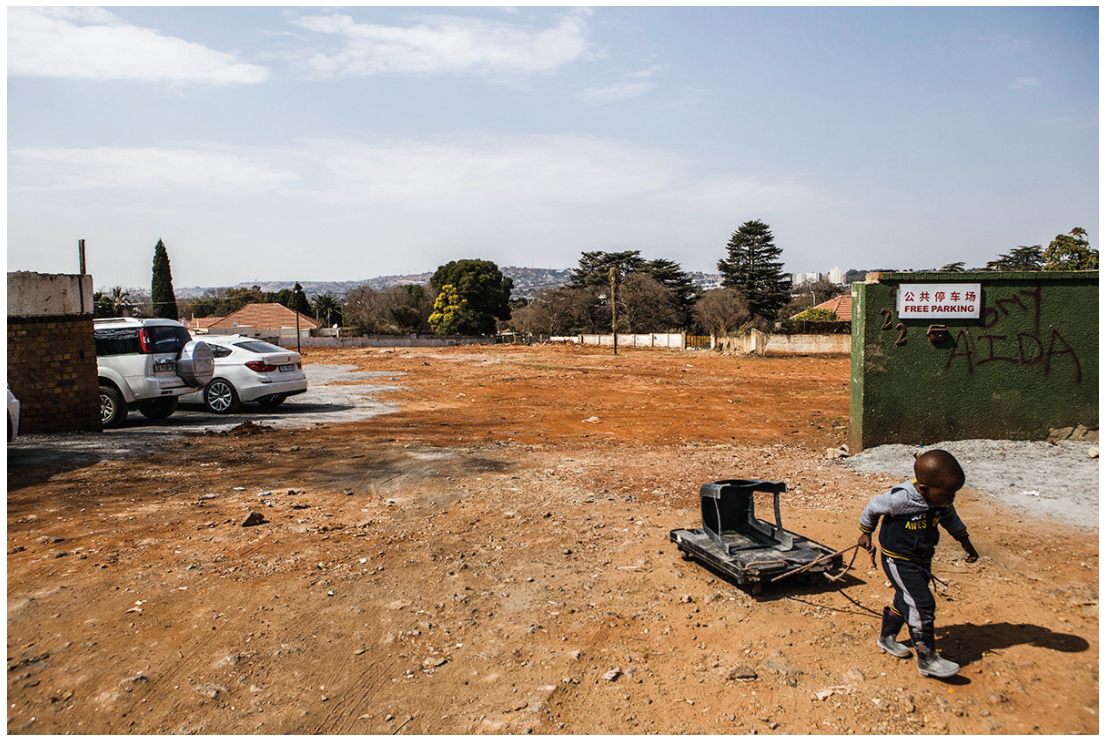

Photograph 1. Open Space (August 2019)

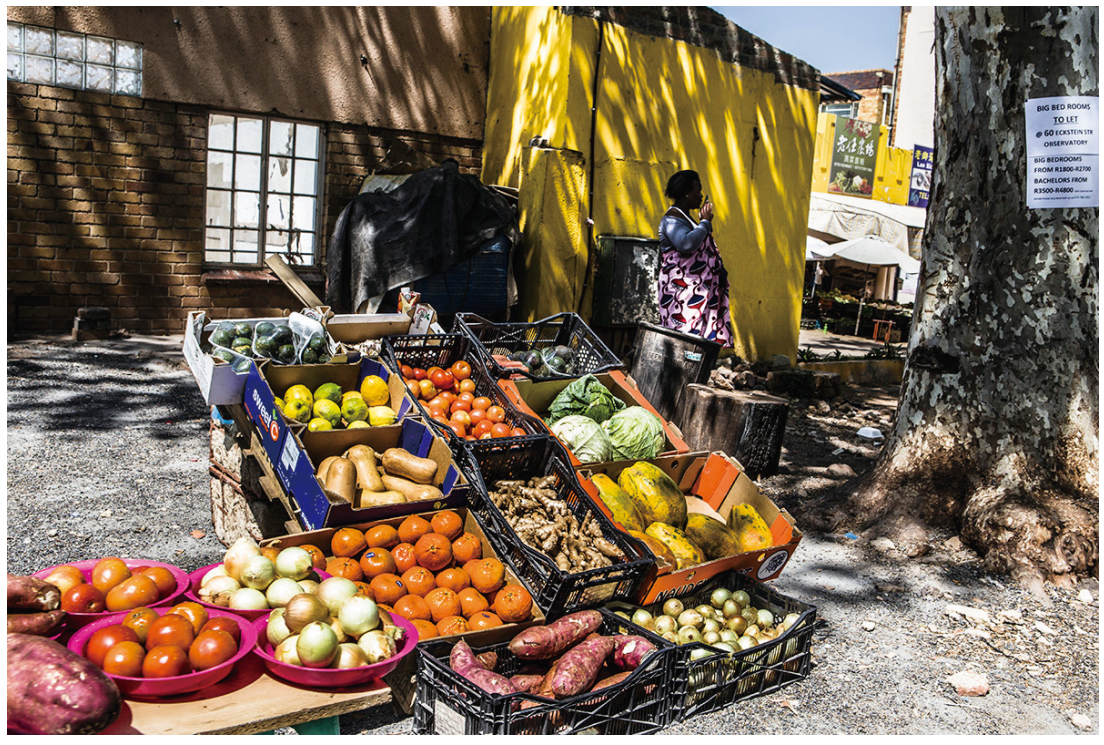

Photograph 2. The Hawkers (September 2019)

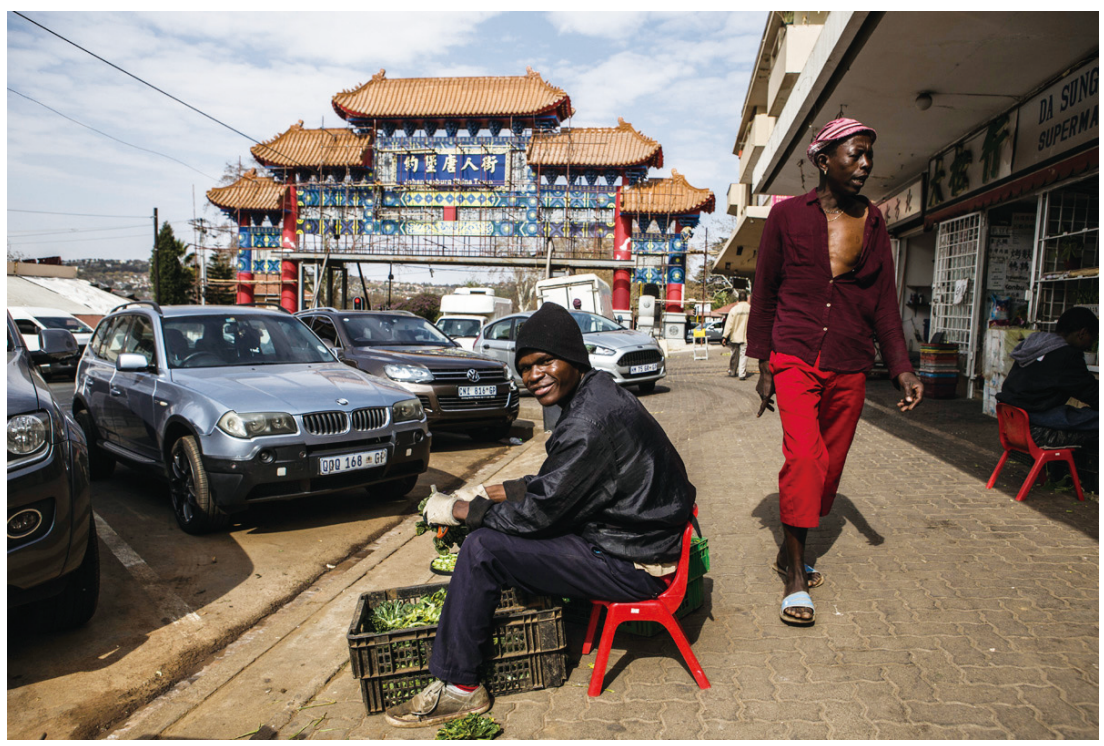

Photograph 3. The Gateway (August 2019) 
wall and the street was claimed by a group of Mozambican women selling vegetables, fruit, and seafood. On Friday afternoons, following the passage of a big truck arriving from Maputo, a queue of customers, mainly Chinese, forms to eagerly buy fresh crabs, shrimp, and fish temporarily kept cold in Styrofoam boxes filled with ice cubes. Over the period of several months, a billboard, written in Chinese and showcasing a rather simple design of a building plan, indicated that the vacant stand would eventually give way to the construction of a considerable mixed-use shopping centre. A few months later, the sign had disappeared and the overgrown vegetation was cleared to provide additional parking possibilities, at the same time pushing the street hawking activity to a little corner (see photos 1 \& 2). These entangled spatial logics and temporalities - merging the not-too-distant past, the transient, and the unknown future - highlight the coexistence of different rhythms while providing a first indication of diverging interpretations regarding the usage of space and the on-going changes in the built environment.

If until the early 1990s, Derrick Avenue was largely characterised by Jewish, and to a lesser extent, Greek residents as well as related spatial markers, the street has since then attracted more and more Chinese migrants. With the advent of democratic elections in 1994, concerns about political uncertainty, and rising crime rates, many of the initial dwellers decided to move out of the neighbourhood, either to more affluent parts of Johannesburg or overseas, opening up a large supply in available accommodation possibilities. The arrival of new residents, initially Taiwanese, who were then joined and gradually overtaken by Mainlanders (lured by business opportunities in trade), also resulted in material changes along the street. This is most visibly symbolised by the construction of two large gates placed at each extremity of Derrick Avenue (see photo 3), as well as the concentration of commercial activities (eateries, grocery stores, and hair salons) and an increase in building densities.

In Johannesburg, those familiar with Cyrildene tend to primarily associate the area with the existence of Chinatown. Once a year, the neighbourhood receives greater attention due to the convening of the Chinese New Year celebrations, drawing in crowds from different parts of the city. Pedestrianised for the day, Derrick Avenue turns into an event. The street is filled with people, either seated at large tables with set menus, queuing at various food stands, or following the dance of the dragon as it collects offerings from all the shops and aimed at chasing away bad spirits while ushering in good fortune. If the food served on this day is quite basic, the majority of this diverse crowd is in any case rather focused on the fireworks and on experiencing a new area, perceived as an exoticised space that operates in parallel to the broader city.

Given its particular aesthetic and visual contrast to the rest of the suburb, dominated by detached houses and a quiet residential atmosphere, ${ }^{1}$ the encounter with difference has become the main form of engagement with Derrick Avenue. This applies as much to the ones attracted by it, as to those rejecting and trying to avoid it, assimilating the physical changes, increased levels of activity, and density along Derrick to a disruption of the suburban way of life. A former resident, who until 1986 lived in an apartment block across the road from the Dragon Garden flats (see photo 12) and whose mother continued to live there until 2008 , recalls being both fascinated with and scared of these changes. "It's a completely different culture that moved into the area and I increasingly felt out of place. The smells and sounds were (and are) so different from the ones I had grown up with." ${ }^{2}$ Standing in front of her former home, she conceded that change, although commonplace, is difficult to accept given that it had wiped out her childhood memories. Adjacent residents, currently living in the neighbourhood, have repeatedly complained to the municipal government about deficient urban management and deviation from building norms and by-laws. The city administration eventually responded and developed a precinct plan that aims to regulate the co-existence of Derrick Avenue with the rest of the suburb. While largely accommodating the changes, the City's ambition is to limit the spatial expansion of Chinatown in order to retain the current character of suburbia all around. ${ }^{3}$

This conceptual and practical divide between a clearly defined inside and outside does not only exist within the reasoning of residents, city planners, and designers, but also transpires from journalistic and scholarly work. Mainly approached through the lens of ethnicity and othering, urban spaces such as Derrick Avenue become easily locked into a particular analytical framework, and as such tend to be alienated from broader urban dynamics and realities. To borrow from Lindsay Bremner, "how we write the city invents it, brings it into being," while "the categories we choose to describe our cities [and the various spaces within] bring them into focus, allow them to exist (or not exist), in very powerful and particular ways" (Bremner 2010: 4, 49). Similar challenges are posed to the realm of visual depictions, given that images can contribute to unsettling and disrupting certain interpretations and mental constructs, while at the same time upholding them (De Boeck and Plissart 2004: 7-10).

With these limitations in mind, we seek to engage this space as a process, as open, constantly moulded, and unfinished, to borrow from Doreen Massey's vocabulary (2005). Our aim is not to disregard the existence of difference, but to consider how Derrick Avenue as a space exists as an integral part of city-making processes and realities. In this context, the articulation between unique and common then ceases to be binary and emerges as an entanglement of urban complexities. The selection of images featured in this essay offers a glimpse of these multiple trajectories, time frames, and imaginations that converge within this street.

A street can be narrated in many ways. Here, Mark Lewis has primarily focused on the interaction between the materiality of the built form and the mundane lived experience of various people linked to Derrick Avenue. The essay first zooms into one of the bigger apartment blocks, comprised of about 45 flats and seven shops on the ground floor. It is situated in the busier section of Derrick Avenue and coincides with the initial appearance of Chinese features. Unlike the majority of buildings along Derrick Avenue, which are either tied to Chinese, Taiwanese, or Hong Kongese capital, this building is owned by Dave, a white Jewish South African, who moved to Cyrildene in the early 1990s, purchasing the block of flats with a business partner (see photo 6). While it is unclear why exactly Chinese migrants chose to concentrate along Derrick Avenue, the early beginnings of Chinatown are often associated with the opening of a noodle place run by a Chinese man who relocated from Yeoville, a neighbourhood currently correlated with a large presence of migrants from different parts of Africa. When asked about the emergence of Chinese markers along the street, Dave, who initially also stayed in Yeoville, alluded to indirectly playing his part in bringing the Chinese to Cyrildene by convincing the owner of the noodle shop to set up his restaurant in his building until he eventually retired back in Taiwan. ${ }^{4}$ Except

1. Cyrildene, largely a middle-class neighbourhood, experienced significant demographic shifts over the last 10 to 20 years, having become racially more diverse. At the same time, newly arrived suburbanites have seldomly challenged the suburban ideal of a conventional, residential, and calm neighbourhood.

2. Interview in Cyrildene, 21 August 2019.

3. Interview with a City official in Johannesburg, 1 June 2018.

4. Series of interviews in Cyrildene, April-May 2018 and July 2019. All names in this essay have been changed. 


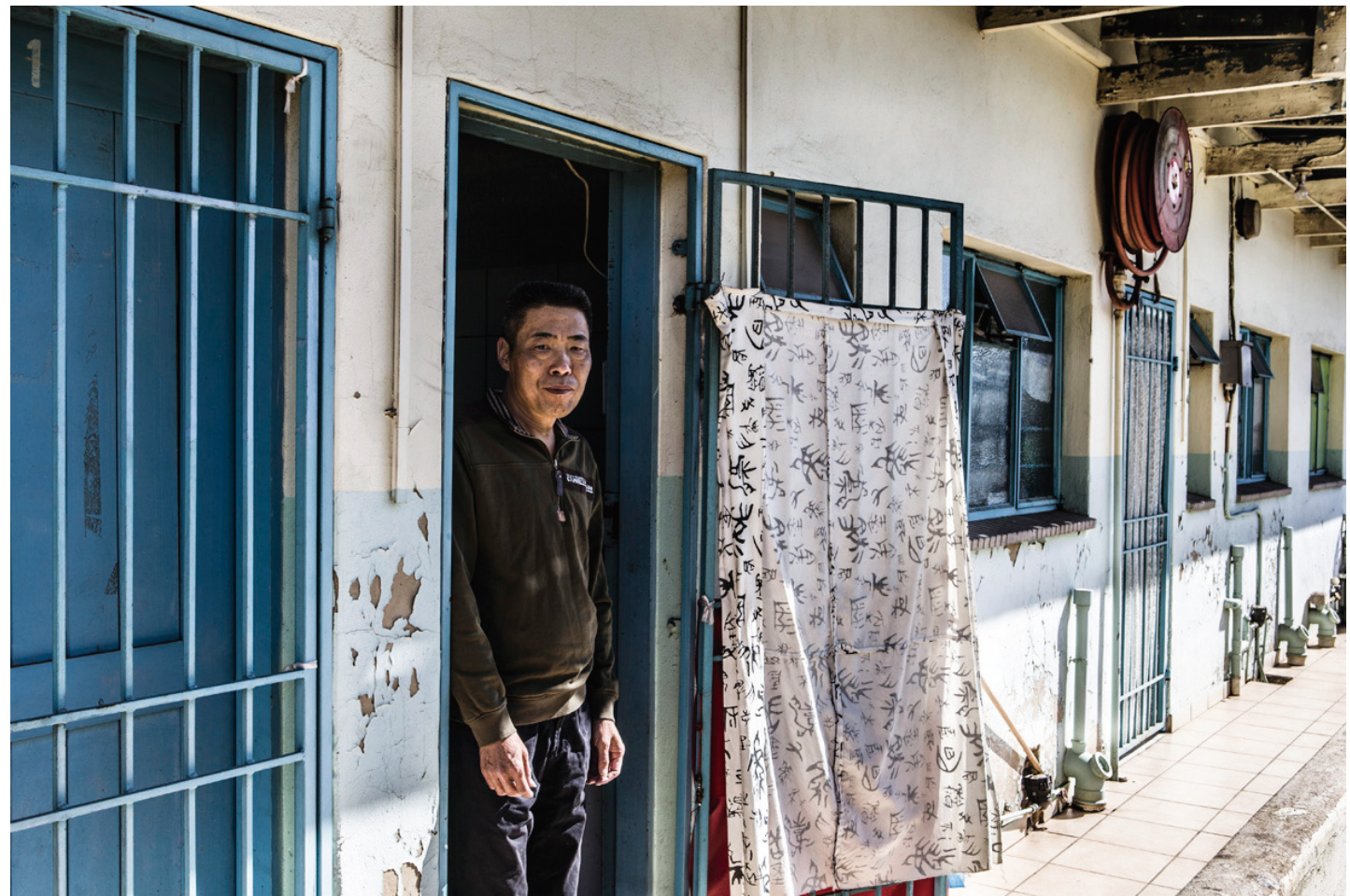

Photograph 4. The Tenant (September 2019)

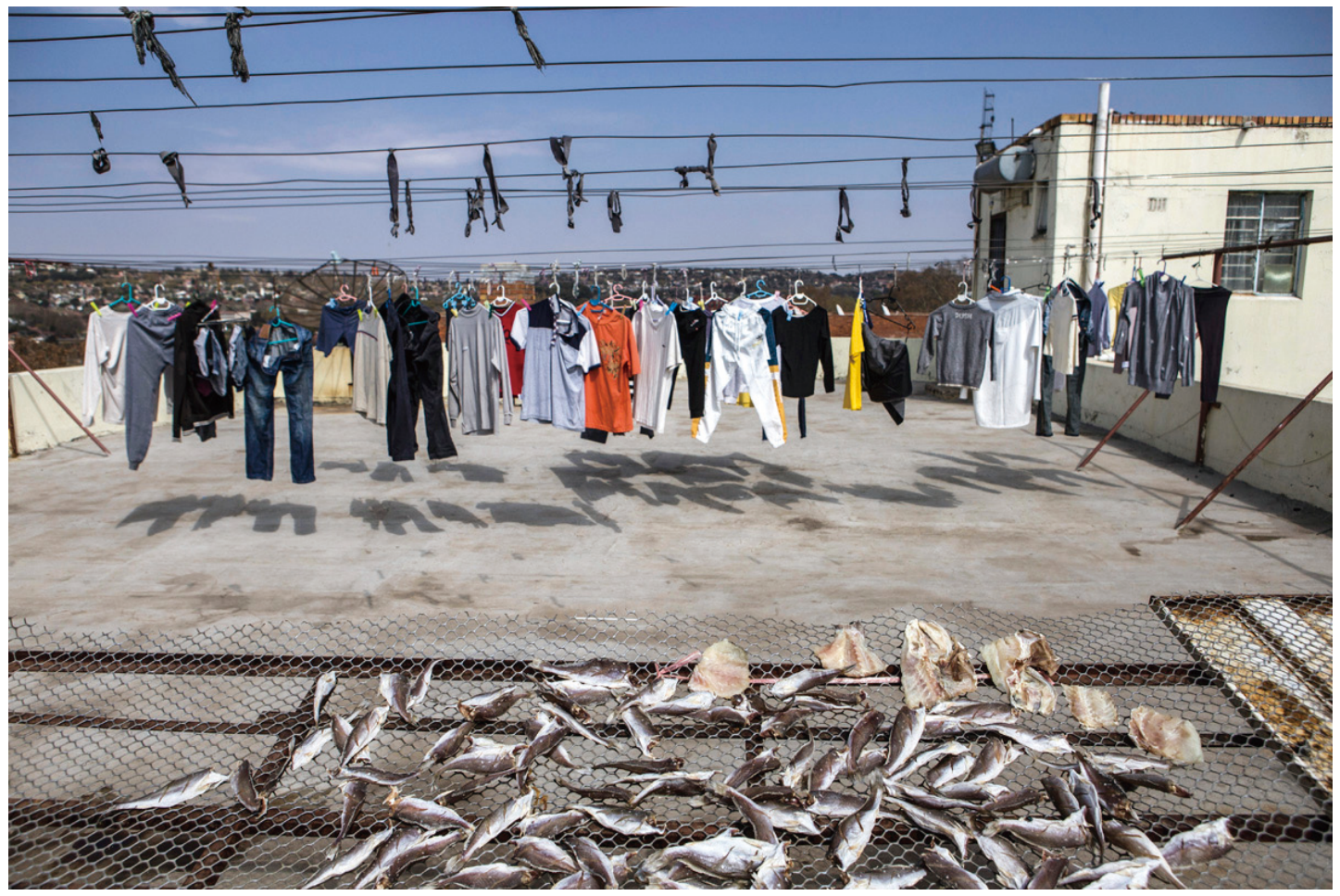

Photograph 5. The Rooftop (September 2019) 


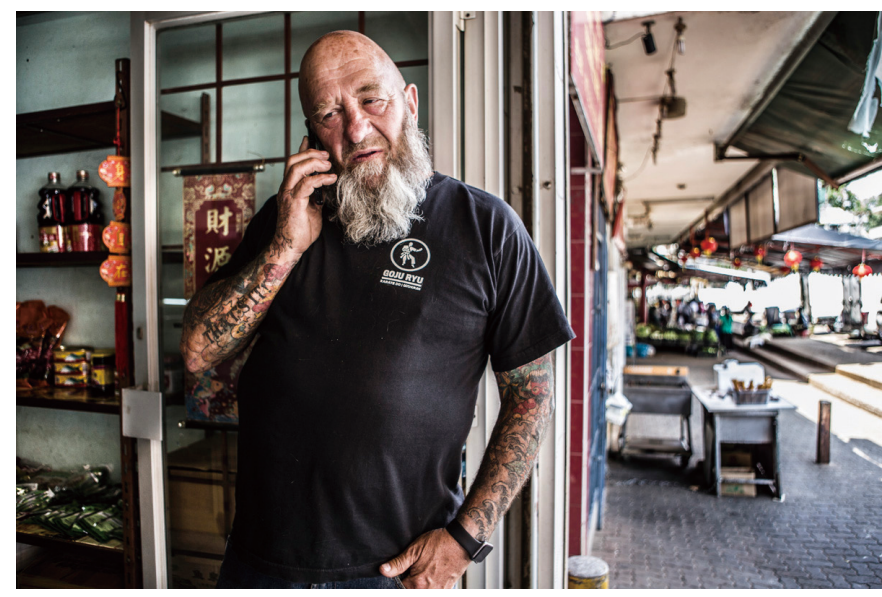

Photograph 6. The Landlord (October 2018)

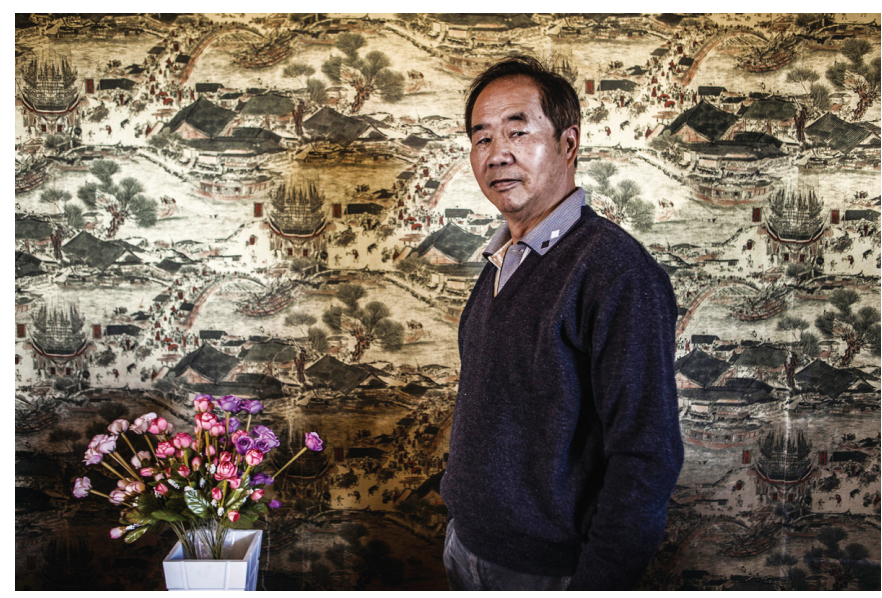

Photograph 8. The Businessman (September 2019)

for one unit being occupied by a Pakistani family, all tenants in this building are Chinese. Most of them work in shops inside the numerous Chineserun malls, located south of Johannesburg's inner city, and commute back and forth on a daily basis. Dwelling aside, the flats, including the balconies, are often also turned into functional spaces for the storage of boxes and supplies, with the rooftop of the building being used to dry not only clothes, but also fish, pak choi (or xiao bai cai 小白菜), and squid (see photos 4 \& 5).

The various portraits of individuals indicate that Derrick Avenue acts as a focal point for a wide range of people. The Zimbabwean baker, the Malawian worker, the Mozambican hawker, the Ghanaian curio seller, the South African caretaker, the Chinese farmer, and the Congolese security guard are only a few examples of those trying to carve out a living in relation to the street's current makeup. Ato, the curio seller, studied and worked in Taiwan for a number of years, where he also learned to speak Mandarin Chinese. Upon relocating to South Africa for business opportunities, he first sold various items at a market in a tourist town about 35 kilometres away from Johannesburg before deciding to try his luck along Derrick Avenue about a year ago. Given that his shop is located in the basement, every day he puts some samples of carved animals, doors, leather belts, and copper bracelets outside, next to the entrance stairway of one of the busiest and most popular restaurants in the street. Mainly targeting Chinese customers, Ato hopes to make use of his linguistic skills and attract interest "by introducing some African features into Derrick Avenue." Amongst those interviewed, most see their current occupation as temporary while they are looking for

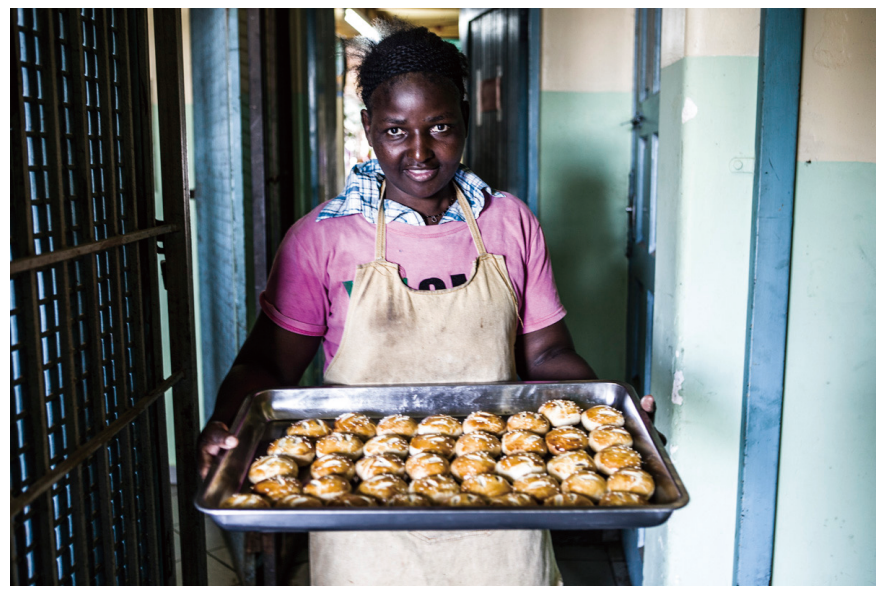

Photograph 7. The Worker (November 2017)

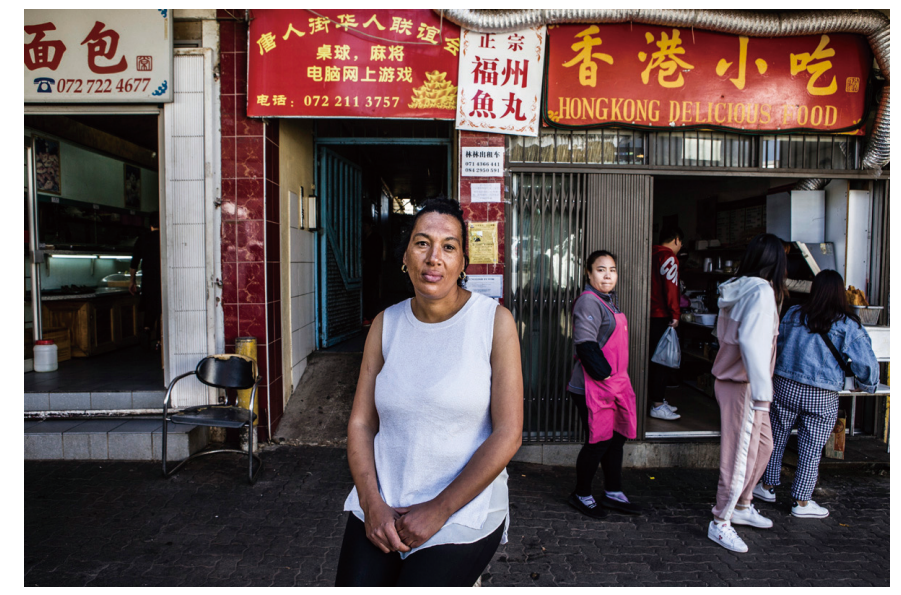

Photograph 9. The Caretaker (September 2019)

other openings, even if Gloria, the caretaker of a building, insisted that God made her come here to take care of the street (see photo 9). ${ }^{6}$

In terms of (visible) business activity, Derrick Avenue is mainly structured around food (see photos $7 \& 11$ ). In the mornings, chefs and kitchen staff can often be seen buying the necessary ingredients directly from the different greengrocers, butcheries, and supermarkets along the street. Many of these greengrocers operate as outlets for Chinese-run farms located outside the city, in areas such as Bronkhorstspruit, about an hour's drive to the northeast of Johannesburg (see photo 10). Apart from attracting individual customers, their main source of income is tied to the interest of other non-Chinese greengrocers operating in various parts of the city or elsewhere, who come to load their mini-vans and trucks. While the Chinese farmers are mostly growing green vegetables, the shops along Derrick combine these with fruit and other veggies purchased at City Deep, a large warehouse market in downtown Johannesburg. If difficult to measure, the gravitational pull based on access to fresh produce, rice, condiments, or Asian specialities has not only linked Derrick Avenue to other parts of the city, but also triggered the presence of additional entrepreneurial activities. These include the aforementioned Mozambican hawkers, people occasionally selling avocados from KwaZulu-Natal (a coastal province in the eastern parts of South Africa)

5. Interview in Cyrildene, 23 August 2019. 
piled on top of a pickup truck, a Chinese man using his minibus taxi to sell fruit sourced from City Deep, as well as someone appearing around lunchtime with a shopping trolley to sell pap (maize flour porridge) and meat, popular among black workers employed along the street and within the wider neighbourhood.

Alongside these activities, which are, all in their own way, contributing to shaping the character and texture of the street, there are those wanting to engage with the area on a larger scale and in more structural ways. Mr. Wang, a well-established businessman, one of the first developers on Derrick Avenue and owner of a four-storey building along the street, thought that the city's Precinct Plan is lacking in ambition (see photo 8). Today semi-retired, his first encounter with the African continent was at the age of 24 when he worked for CCECC (China Civil Engineering Construction Company) in various places in West Africa. In 1990, he moved to South Africa, first to Newcastle in KwaZulu-Natal, where a number of Taiwanese industrialists had opened factories, and then to Johannesburg, where he started an importexport business, at the time located in Pritchard Street in the CBD. Inside his massive house, located further up the road from Derrick Avenue in the leafy part of an adjacent suburb, the wall in one of the reception rooms is filled with framed pictures of him shaking hands with both domestic and international dignitaries, signalling a man who seems to be well connected. Referring to Johannesburg's challenges in terms of urban sprawl, and given the city's insufficient levels of economic activity, Mr Wang is in favour of widening the commercial footprint of the precinct and increasing its building density. ${ }^{7}$ His intention, although unlikely to materialise in this form, is to tear down his partially closed building $^{8}$ along Derrick, since he has already acquired some of the adjacent plots, and build a 10-storey mixed-use structure with several floors dedicated to shopping, offices, and food courts. While nearby residents largely associate the presence of Chinese spatial features and street-level activities as impacting negatively on the neighbourhood and on their property prices, people like Mr. Wang or Dave the landlord are eager to increase the appeal (and value) of the

7. Interview in Observatory, 28 June 2018 and 2019.

8. It used to accommodate various businesses, including a Chinese library, a Chinese language newspaper, as well as a karaoke bar.

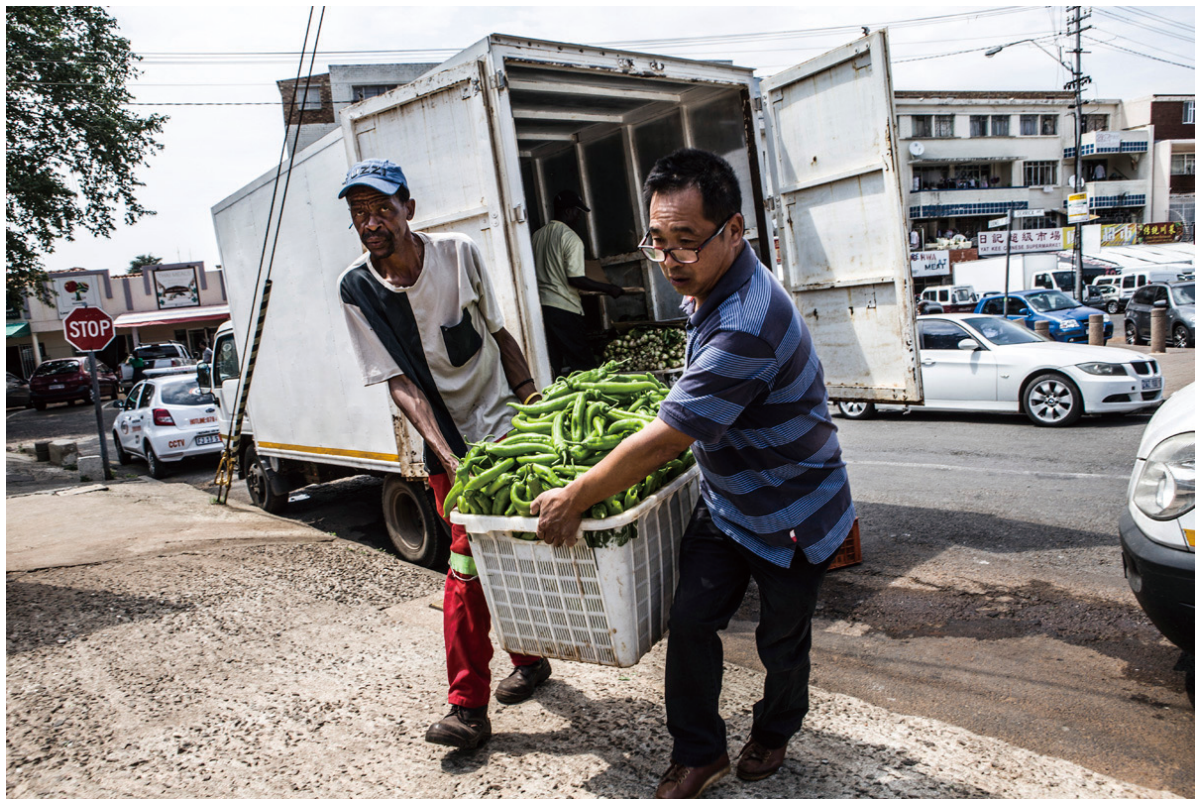

Photograph 10. The Farmers (October 2017)

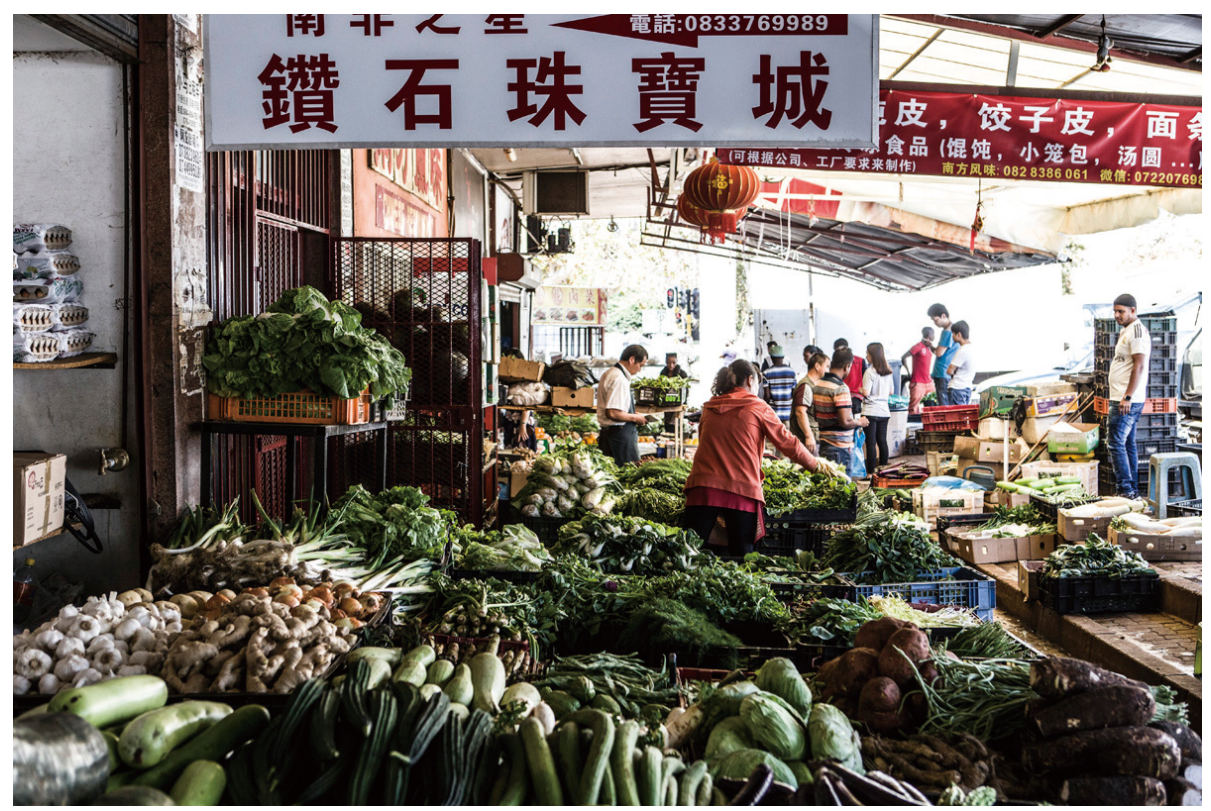

Photograph 11. The Market (March 2018)

\section{References}

BREMNER, Lindsay. 2010. Writing a City into Being: Essays on Johannesburg, 1998-2008. Johannesburg: Fourthwall Books.

COLE, Teju. 2017. Blind Spot. New York: Random House.

DE BOECK, Filip, and Marie-Françoise PLISSART. 2004. Kinshasa: Tales of the Invisible City. Leuven: Leuven University Press.

MASSEY, Doreen. 2005. For Space. London: Sage Publications 


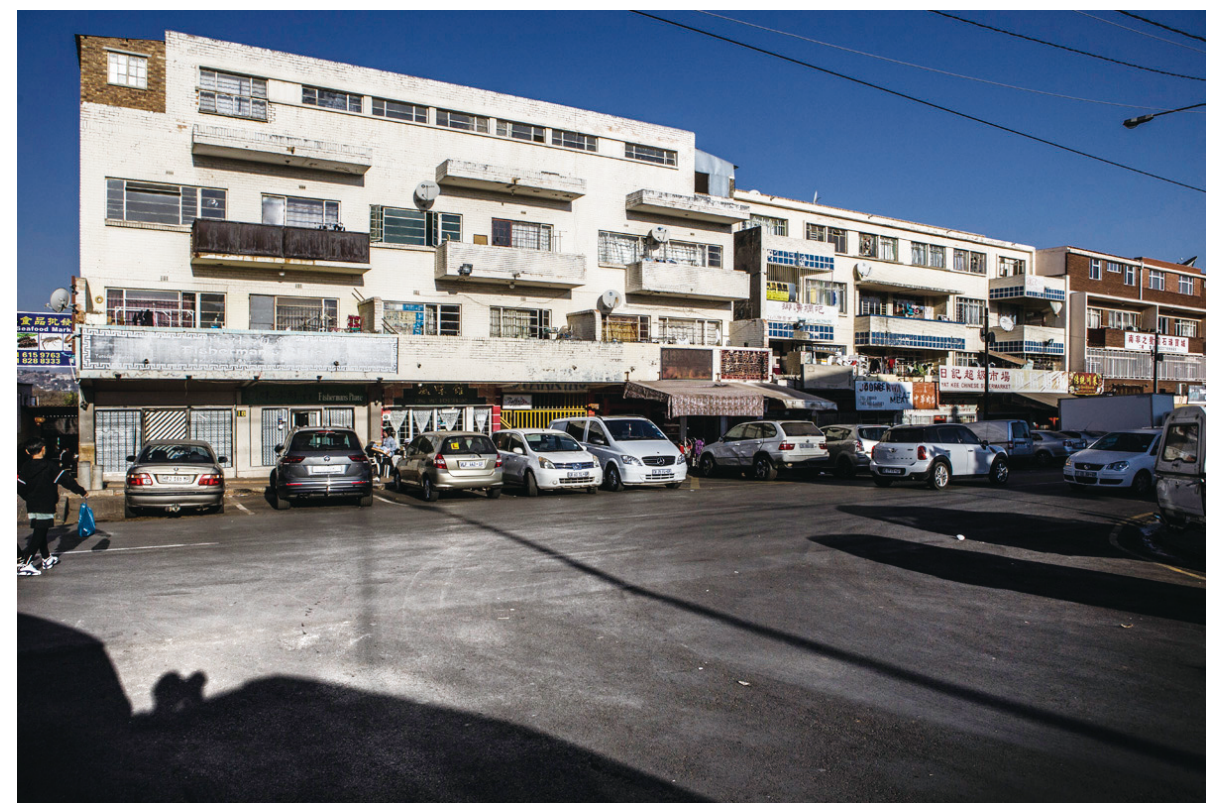

Photograph 12. Dragon Garden Flats (August 2019)

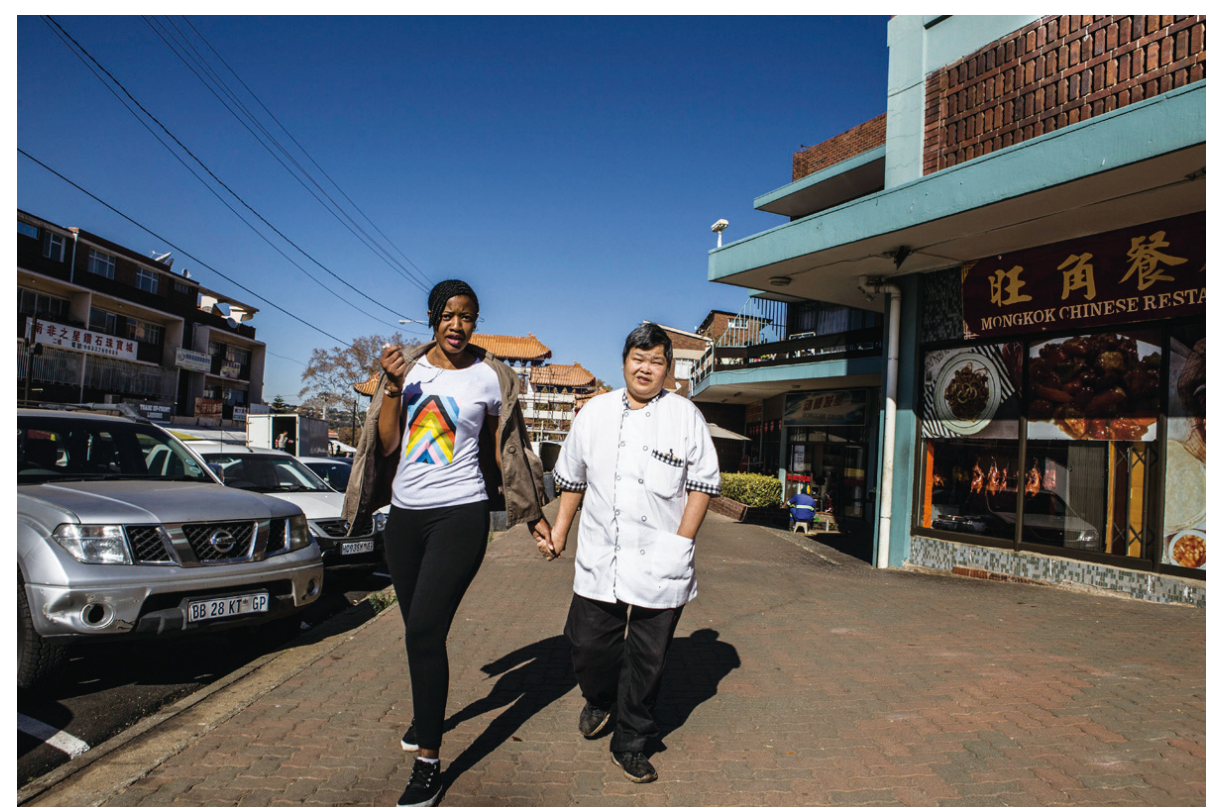

Photograph 13. The Street (June 2018)

\section{Captions}

Photograph 1. Open Space Photograph 2. The Hawkers Photograph 3. The Gateway Photograph 4. The Tenant Photograph 5. The Rooftop Photograph 6. The Landlord
Photograph 7. The Worker

Photograph 8. The Businessman

Photograph 9. The Caretaker

Photograph 10. The Farmers

Photograph 11. The Market

Photograph 12. Dragon Garden Flats

Photograph 13. The Street area through an even greater focus on "ethnic" markers. Drawing parallels to Maboneng, a privately regenerated and gentrified section in downtown Johannesburg surrounded by a rundown neighbourhood, both envision the future of Derrick Avenue as a proper, regulated, and up-market Chinatown. Their ambition would be to make this place look like other Chinatowns in Western Europe or North America, and insert it as part of the city's tourism itinerary. Others, however, point to the existing demographics and socio-economic status of those operating along the street, arguing that a significant upgrade, subsequently attracting a different clientele, would probably push out those who turned Derrick Avenue into what it is today (see photo 13).

At the time of writing, changes have probably already occurred, whether this might be businesses closing or opening, or people leaving or arriving. More broadly, this reality points to a street that exists in a fluid state and in motion, merging both transient and more structural aspects. The multiple imaginations and interpretations this entails (and requires) means wrestling with the relative rigidity of writing and temporal fixity of photography, while grappling with what Teju Cole has called the existence of a "constant blind spot" where we only get to see a small part of what we are looking at (Cole 2017). As a result, the embedding of Derrick Avenue within much broader urban phenomena and in conversation with socio-economic conjunctures could be one way of narrating and visualising this street in more flexible ways.

I Dr. Romain Dittgen is an Associate Researcher at the African Centre for Migration and Society (University of the Witwatersrand) in Johannesburg, South Africa (rom.dittgen@gmail.com).

I Mark Lewis is an Urban Photographer based in Johannesburg, South Africa (marklewisafrica@gmail.com).

I Dr. Gerald Chungu is an Architect and Urban Designer at the School of Architecture and Planning (University of the Witwatersrand) in Johannesburg, South Africa (gerald. chungu@wits.ac.za). 